\title{
Bimetallic Nanocatalysts PtCu and PtNi for Fuel Cells
}

\author{
${ }^{1}$ Kryviy Rih National University, Kriviy Rih, Ukraine, hmchernikova@gmail.com \\ ${ }^{2}$ Radiation Monitoring Devices, Inc. USA, yogorodnik@ rmdinc.com
}

\begin{abstract}
The physical mechanisms of heterogeneous catalytic oxidizing reactions methanol oxidation using bimetallic film layered mechanically strained PtNi and PtCu-based catalysts are reviewed. The main research methods are theoretical calculations based on the density functional theory and the "ab initio" pseudopotential method. The work illustrates that the mechanical stress and the presence of dissociated oxygen have the greatest impact on increasing electron bimetallic catalyst activity during the oxidation of methanol with using bimetallic layered mechanically strained PtNi and PtCu-based catalysts. The compression of the platinum film pushes the electron density outside the film and it gives the density an elongated form and increases the chemical and absorption activity of the film.
\end{abstract}

Keywords: heterogeneous catalytic, bimetallic film catalysts, methanol oxidation, functional theory, crystal lattice, density, energy spectrum, fuel cells.

Received 18 May 2020; Accepted 15 June 2020.

\section{Introduction}

Nanoparticles and nanostructured materials are actively studied in many fields of science. Such areas include nanoenergy, in which fuel cells are one of the most promising technologies for generating electricity. Fuel cells (PE) are devices for the direct conversion of chemical energy of fuel into electrical energy as a result of electrochemical reactions. The development and implementation of fuel cells is still an urgent task in the development of new catalytic fuel oxidation systems [1-5].

According to existing scientific research in the development of nanoenergy, electrocatalysts must meet the following requirements: be porous [6], have adequate electronic conductivity, stability in the electrolyte, selectivity for redox reactions, adsorption, catalytically active and durable [7].

Currently, platinum group materials are widely used in low-temperature fuel cells as catalysts for chemical processes. In catalytic processes, Pt has advantages over other chemical elements due to the unfilled electron orbital $5 \mathrm{~d}$. Its main disadvantages are degradation during long-term operation in PE, as well as high cost. The solution to these problems is associated with the development of multicomponent catalytic systems based on platinum with the inclusion of other metals $[8,9,10]$. This requires the use of highly efficient catalysts, which could combine high reaction activity and extended service life of these devices. Their development strategies depend on a detailed understanding of the mechanisms of fuel oxidation and oxygen reduction [11].

For multi-component catalytic systems, their most active sites on the catalyst surface are the most important, which is a key point for their development. The inclusion of other chemical elements in platinum affects the stability of the system as a whole. In [12-19], bimetallic catalysts $\mathrm{Pt}-\mathrm{M}(\mathrm{M}: \mathrm{Fe}, \mathrm{Ni}, \mathrm{Cr}, \mathrm{Cu}, \mathrm{Co})$ were studied to study the mechanisms of oxygen reduction. Scientists have established a relationship between the increase in catalytic activity and the compression and stretching of the crystal lattice, the deformation of the lattice, the shift of the d-zone in bimetallic catalysts.

Therefore, for practical success in the development of catalytic structured and functional materials, for example in energy conversion processes, it is necessary to know quantitative information about the basic concepts of the catalytic reaction [20]. This will at least predict what are the optimal opportunities for chemical reactions and what materials can be selected for the 
production of catalysts.

In this paper, we consider the physical mechanisms of heterogeneous catalytic oxidation reactions, ie the oxidation of methanol using bimetallic catalysts based on $\mathrm{PtNi}$ and $\mathrm{PtCu}$. For modeling and theoretical calculations, we use the method of electron density functional theory and the ab-initio pseudopotential method.

\section{Methods and objects of computing}

The basic states of the alimentary-nuclear systems were manifested by a self-consistent solution of the Kohn and Sham equations, since only electronic changes were determined with fixed atomic bases. Following Kohn and Sham [21], the electron density was recorded in terms of occupied orthonormal single-particle wave functions:

$$
n(\vec{r})=\sum_{i}\left|\psi_{i}(\vec{r})\right|^{2}
$$

The point on the surface of the potential energy in the Born-Oppenheimer approximation was determined by a minimum concerning the wave functions of the energy functional:

$$
E\left[\left\{\psi_{i}\right\},\left\{R_{j}\right\},\left\{\alpha_{v}\right\}\right]=\sum_{i} \int_{\Omega} d^{3} r \psi_{i}^{*}(\bar{r})\left[-\frac{\hbar^{2}}{2 m} \nabla^{2}\right] \psi_{i}(\vec{r})+U\left[\{n(\vec{r})\},\left\{R_{j}\right\},\left\{\alpha_{v}\right\}\right],
$$

where $\left\{R_{j}\right\}$ - the coordinates of atomic shafts, $\left\{\alpha_{v}\right\}-$ all possible external influences on the system.

Because the calculation algorithm implies translational symmetry in the investigated atomic system, an artificial super-lattice of the tetragonal type was created. To obtain the film structure, the lattice parameters along the axes $\mathrm{OX}, \mathrm{OY}, \mathrm{OZ}$, had a ratio of 1: 1: 2. The parameters of the super-lattice and the atomic basis are determined by the object of the study.

The parameters of the platinum lattice are larger than those of nickel and copper, which allows the process to create compressed layers Pt, either by the epitaxial buildup of the layers $\mathrm{Pt}$ on the substrate $\mathrm{Ni}$ or $\mathrm{Cu}$ or the cultivated (synthesized) alloy of a given composition $\left(\mathrm{Pt}_{\mathrm{x}} \mathrm{Ni}_{1-\mathrm{x}}, \mathrm{Pt}_{\mathrm{x}} \mathrm{Cu}_{1-\mathrm{x}}\right)$.

To study the physical mechanisms of the methanol oxidation reaction on platinum-containing catalysts for the comparative analysis, three groups of nano-objects with a thickness of 4 atomic layers containing 32 atoms in the base, which in the first group are divided into objects: film $\mathrm{Pt}$; film $\mathrm{Cu}$; film $\mathrm{Ni}$; film heterostructure consisting of two atomic layers of nickel or coppercoated on two sides on one platinum layer.

Next, the atomic systems described above, supplemented by two oxygen atoms, were located in the interstate positions of the surface layers $\mathrm{Pt}$ and alloys $\mathrm{Pt}_{\mathrm{x}} \mathrm{Ni}_{1-\mathrm{x}}, \mathrm{Pt}_{\mathrm{x}} \mathrm{Cu}_{1-\mathrm{x}}$.

The third model group was based on the second group of objects with an addition on the surface of methanol molecules. Also, for the possibility of evaluating changes in atomic systems, an isolated methanol molecule and two-layer platinum films were additionally calculated.

\section{Results of calculation}

According to the results of calculations using the author's software code [22], the spectral characteristics of the developed model atomic systems, the spatial distributions of the density of valence electrons, and their intersection were determined.

Analyzing our obtained results of theoretical calculations, we found that when platinum is deposited on a $\mathrm{Ni}$ or $\mathrm{Cu}$ substrate, the distance between $\mathrm{Pt}-\mathrm{Pt}$ atoms is reduced, which in turn increases the catalytic activity of platinum. Reducing the length of the $\mathrm{Pt}-\mathrm{Pt}$ bond promotes the formation of more favorable active centers for oxygen chemisorption. The obtained experimental results correlate with the results of other authors [23, 24].

To study the physical mechanisms of the methanol oxidation reaction on platinum-containing catalysts for comparative analysis, we created pure 4-layer $\mathrm{Cu}$ and $\mathrm{Ni}$ films with the addition of an oxygen atom in the position between the surface atoms of the $\mathrm{Cu}$ film and the $\mathrm{Ni}$ film. Figure 1 shows the spatial distributions of the valence electron density for the 32 atomic $\mathrm{Cu}$ film in the planes 110 ) and (100) with the addition of a molecule of methanol and atomic oxygen.

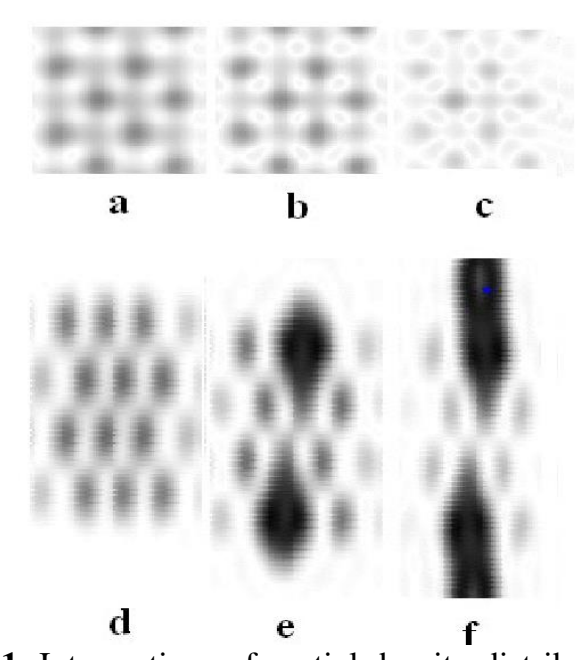

Fig. 1. Intersections of spatial density distributions of valence electrons in planes (110) and (100) 32-atoms film $\mathrm{Cu}$ atom of methanol on the surface (the center of the molecule is located above void between atoms on the surface layer of catalyst) and the oxygen atom of the molecule of $\mathrm{O}_{2}$ is dealt face up in the position between the surface atoms of $\mathrm{Cu}$ catalysts: $(\mathrm{a}, \mathrm{d})$ film $\mathrm{Cu}$; (b, e) film $\mathrm{Cu}$ with the addition of the atom $\mathrm{O}$; (c, f) $\mathrm{Cu}$ film with atom $\mathrm{O}$ and molecule of methanol. 

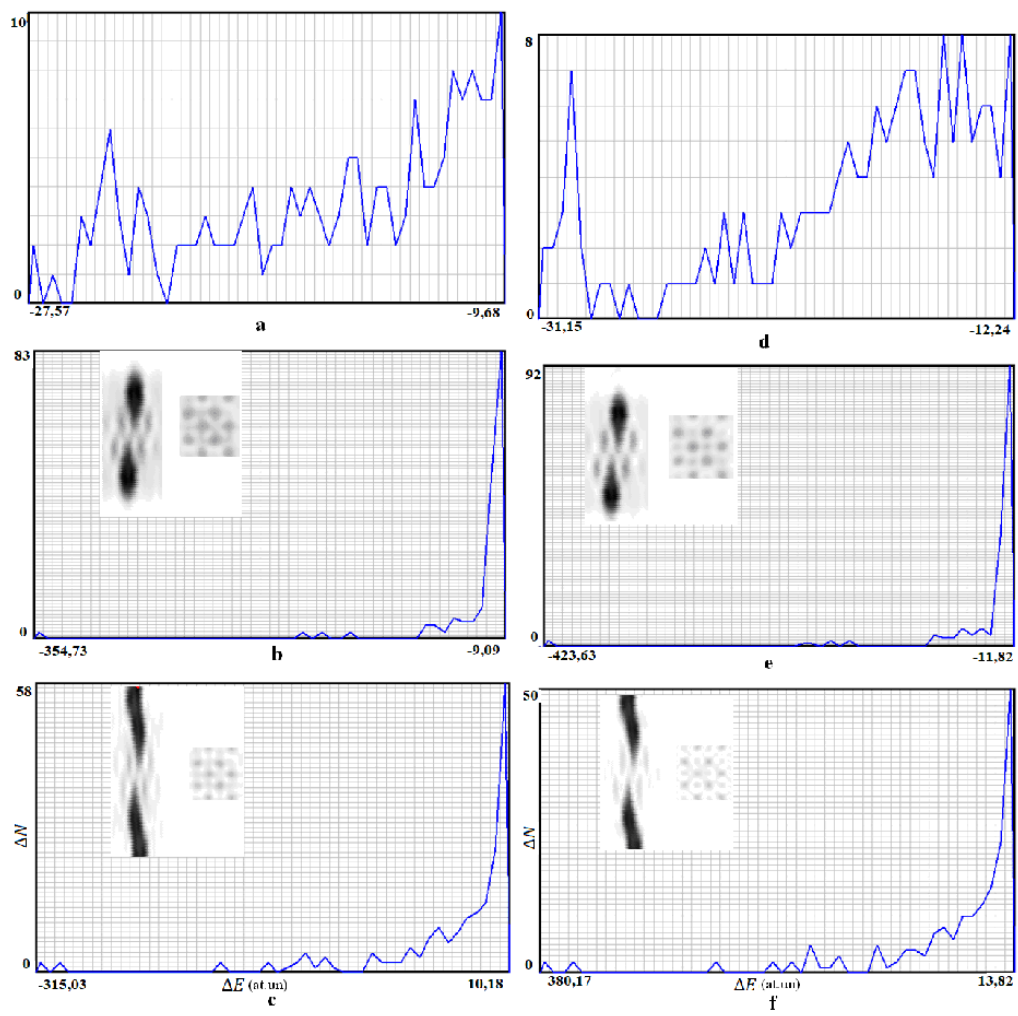

Fig. 2. Electronic spectra of the valence electrons for 4 layers film $\mathrm{PtCu}(\mathrm{a}, \mathrm{b}, \mathrm{c})$ with lattice $\mathrm{Cu}(\mathrm{a}=3.615 \AA)$ and PtNi (d, e,f) with lattice $\mathrm{Ni}(\mathrm{a}=3.524 \AA$ ) with absorption atoms on the surface: a) 4 layers film PtCu; b) 4 layers film $\mathrm{PtCu}$ adding atom $\mathrm{O}$; c) 4 layers $\mathrm{PtCu}$ with atom $\mathrm{O}$ and molecule of methanol; d) 4 layers film PtNi;

e) 4 layers film PtCu adding atom O; f) 4 layers film PtNi with atom $\mathrm{O}$ and molecule of methanol.

Figure 2 shows the distributions of electrons in energy areas for the g point superlattice Brillûen zone above the described systems. In the analysis of distributions that meet the 4 layers of brief films $\mathrm{PtCu}$ and $\mathrm{PtNi}$, with added oxygen atoms and molecules of methanol, it is evident that there is a significant difference in the electronic properties of systems, analyzed above for adding the atomic the oxygen in the system. The character of the distribution of the electrons as the energies and space changing from uniform to the inherent systems with internal electric fields and energy barriers: the emerging spatial area with locally higher charge in the neighborhood of the oxygen atoms, and the distribution (sorting) of electrons to energies on the distribution of the dominant maximum energy near the Fermi, thereby increasing the catalytic activity of the films.

\section{Conclusions}

The methods of the functional of electron density and pseudopotential from the first principles obtained distributions of the density of valence electrons and electronic energy spectra of bimetallic catalysts based on $\mathrm{Pt}$ to determine the mechanisms of their increased catalytic activity. It was found that mechanical stresses and the presence of dissociated oxygen play the greatest influence on the increase of the electronic activity of the catalyst.

Chernikova O.M. - senior lecturer at the Department of Physics, Candidate of Physical and Mathematical Sciences;

Ogorodnik Y.V. - senior researcher.

[1] B.-W. Zhang, H.-L. Yang, Y.-X. Wang, S.-X. Dou, H.-K. Liu, Advanced Energy Materials 8(20), 1703597, (2018) (doi: 10.1002/aenm.201703597).

[2] S. Sui, X. Wang, X. Zhou, Y. Su, S. Riffat \& C. Liu, Journal of Materials Chemistry A 5(5), 1808, (2017) (doi: 10.1039/c6at08580f).

[3] B.W. Zhang, C. L. He, Y.X. Jiang, M.H. Chen, Y.Y. Li, L. Rao, S.G. Sun, Electrochem. Commun. 25(105), (2012) (doi: 10.1039/j.elecom.2012.09.007).

[4] C. Wang, D. Li, M. Chi, J. Pearson, R.B. Rankin, J. Greeley, Z. Duan, G. Wang, D.van der Vliet, K.L. More, N.M. Markovic, V.R. Stamenkovic, J. Phys. Chem. Lett. 3, 1668, (2012) (doi: 10.1021/jz300563z).

[5] Devid Sebastian, Vansinzo Baglio, J. Catalists 7(310), (2017) (doi: 10.3390/catal7120370). 
[6] P. Yang, X. Yuan, H. Hu, Y. Liu, H. Zheng, D. Yang, Q. Zhang, Advanced Functional Materials 28(1), 1704774, (2017) (doi: 10.1002/adfm.201704774).

[7] Z. Zhang, J. Sun, F. Wang, L. Dai, Angewandte Chemie International Edition 57(29), 9038 (2018) (doi: 10.1002/anie.201804958).

[8] H.A. Gasteiger, S.S. Kocha, B. Sompalli, F.T. Wagner, Appl. Catal. B Environ 56, 9 (2005) (doi: 10.1002/j.apcatb.2004.06.021).

[9] D. Sebastián, A. Serov, I. Matanovic, K. Artyushkova, P. Atanassov, A.S.S. Aricò, V. Baglio, Nano Energy 34, 195 (2017) (doi: 10.1016/j.nanoen.2017.02.039).

[10] Yoshiyuki Show, Yutavo Ueno, J. Nanomaterials 7(2), 31 (2017) (doi: 10.3390/ nano7020031).

[11] S. Kuln, P. Strasser, Springer Catalysis J. 59, 1628 (2016) (doi: 10.1007/s11244-016-0682-z).

[12] Q. Wang, S. Chen, F. Shi, K. Chen, Y. Nie, Y. Wang, Z. Wei, Advanced Materials J. 28(48), 10673 (2016) (doi: 10.1002/adma.201603509).

[13] L. Bu, S. Guo, X. Zhang, X. Shen, D. Su, G. Lu, X. Huang, Nature Communications 7, 11850 (2016) (doi: 10.1038/ncomms11850).

[14] G.-H. Wang, J. Hilgert, F.H. Richter, F. Wang, H.-J. Bongard, B. Spliethoff, F. Schüth, Nature Materials 13(3), 293 (2014) (doi: 10.1038/nmat3872).

[15] D. Guedes-Sobrinho, R.K. Nomiyama, A.S. Chaves, M.J. Piotrowski, J.L.F. Da Silva, J. Phys. Chem. C 119, 15669 (2015) (doi: 10.1021/acs.jpcc.8b12219).

[16] X. Huang, Z. Zhao, L. Cao, Y. Chen, E. Zhu, Z. Lin, M. Li, A. Yan, A. Zettl, Y.M. Wang, J. Science, 348, 1230 (2015) (doi: 10.1126/science.aaa8765).

[17] X. Zhao, S. Chen, Z. Fang, J. Ding, W. Sang, Y. Wang, J. Zeng, Journal of the American Chemical Society 137(8), 2804 (2015) (doi: 10.1021/ja511596c).

[18] P. Mani, R. Srivastava, P. Strasser, J. Power Sources 196, 666 (2011) (doi: 10.1016/j.jpowsour.2010.07.047).

[19] Y. Liao, G. Yu, Y. Zhang, T. Guo, F. Chang, C.-J. Zhong, The Journal of Physical Chemistry C 120(19), 10476 (2016) (doi: 10.1021/acs.jpcc.6b02630).

[20] C. Torborg, Adv. Synth. Catal. 351, 3027 (2009) (doi: 10.1002/adsc.200900587).

[21] G.B.Bachelet, D.R. Hamann, M. Schluter, Physical Review B, 26, 4199 (1982).

[22] R.M. Balabay, N.V. Grishchenko, J Photoelectronics 8, 25 (1998).

[23] R. Loukrakpam, J. Luo, T. He, Y. Chen, Z. Xu, P.N. Njoki, C.-J. Zhong, The Journal of Physical Chemistry C 115(5), 1682 (2011) (doi: 10.1021/jp109630n).

[24] M.C. Escaño, E. Gyenge, H. Nakanishi \& H. Kasai, Journal of Nanoscience and Nanotechnology 11(4), 2944 (2011) (doi: 10.1166/jnn.2011.389).

\title{
О.М. Чернікова ${ }^{1}$, Я.В. Огородник ${ }^{2}$
}

\section{Біметалічні нанокаталізатори PtCu та PtNi для паливних елементів}

\author{
${ }^{1}$ Криворізький начіональний університетКривий Рiг, Україна, hmchernikova@ gmail.com \\ ${ }^{2}$ Radiation Monitoring Devices, Inc., yogorodnik@ rmdinc.com
}

\begin{abstract}
Ми розглядаємо фізичні механізми гетерогенних каталітичних окислювальних реакцій окислення метанолу з використанням біметалічних плівкових шаруватих механічно напружених каталізаторів на основі $\mathrm{PtNi}$ та $\mathrm{PtCu}$. Основними методами дослідження $\epsilon$ теоретичні розрахунки, засновані на теорії функціональної електронної густини та методі псевдопотенціалів "ab initio". Робота ілюструє, що механічне напруження та наявність дисоційованого кисню мають найбільший вплив на підвищення каталітичної активності електронного біметалічного каталізатора під час окислення метанолу 3 використанням біметалічних шаруватих механічно напружених каталізаторів на основі PtNi тa PtCu. Стиснення платинової плівки виштовхує електронну густину назовні плівки, і вона надає густині витягнуту форму збільшуючи хімічну та поглинальну активність плівки.

Ключові слова: гетерогенні каталізатори, біметалічні плівкові каталізатори, окислення метанолу, теорія функціоналу, кристалічна решітка, густина, енергетичний спектр, паливні елементи.
\end{abstract}

